\title{
CONCEPT OF MAQASYID SYARIAH FAMILY SAKINAH IN THE AL- MISBAH TAFSIR BY MUHAMMAD QURAISH SHIHAB
}

\author{
Nurhadi \\ Islamic High School (STAI) Al-Azhar Pekanbaru \\ Melayu, Sukajadi, Kota Pekanbaru, Riau, Indonesia 28122 \\ Email:alhadijurnal@gmail.com \\ Mawardi Dalimunthe \\ State Islamic University of Sultan Syarif Kasim Riau \\ Tuah Madani, Tampan, Kampar, Riau, Indonesia 28293 \\ Email: mawardidalimunthe@gmail.com
}

\begin{tabular}{c|c|c}
\hline Received: & Revised: & Approved: \\
04/03/2019 & $17 / 05 / 2019$ & $22 / 06 / 2019$ \\
\hline
\end{tabular}

DOI: http:/ /dx.doi.org/10.32332/akademika.v24i1.1619$$
\text { (c) (†) (O) }
$$

Concept of Maqasyid Syariah Family Sakinah In The Al-Misbah Tafsir By Muhammad Quraish Shihab Licensed Under a Creative Commons Attribution-ShareAlike 4.0 International License
\end{abstract}

\begin{abstract}
The concept of sakinah family according to Muhammad Qurasih Shihab in Tafsir Al-Mishbah there are ten basic constructs, namely: 1). Marriage unites spirituality (mind) and body. 2). Marriage brings calm. 3). Know each other. 4). Love each other. 5). Love each other. 6). Biological channeling. 7). Sourced from all family members. 8). Its function brings together two large families. 9). Sourced from the heart (heart), then radiated outward in the form of activity (husband and wife). 10). Sakinah family strongly supports the effectiveness of worship to God. Ten constructs, the essence of Maqasyid sharia from the concept of the sakinah family according to Muhammad Quraish Shihab in the interpretation of AlMishbah is mahabbatullah (love of Allah). Love (mawaddah) is a tree that thrives in the heart. The root is humility to the lover (warahmah), the trunk is the introduction to him, the branch is fear of God and the creature must not let anyone stain it, the leaves are shy to shame and humiliation, the
\end{abstract}


fruit is the unity of the heart that gives birth to cooperation, the flowers are mutually guarding each other's honor and closing the other's shame, the seed is calm (sakinah), while the water that watering it is remembering and mentioning his name. The thinking of Muhammad Quraish Shihab about sakinah family in the interpretation of al-Mishbah in terms of the development of Islamic family law in Indonesia that the concept of sakinah family is very relevant to the Marriage Law, because his concept according to article 1 is to establish a happy and eternal family based on the Godhead The Almighty.

Keywords: Concept, Maqasyid Syariah, and Sakinah Family

\section{A. Introduction}

Humans were created from one self, ${ }^{1}$ namely the Prophet Adam and his origin were created from the ground. ${ }^{2}$ He resides in heaven. Although heaven is full of pleasure, but Adam still does not feel perfect before there are other friends of his kind. So God made $\mathrm{Eve}^{3}$ from the left rib of the prophet Adam, to be his life partner (his wife). ${ }^{4}$ This is where human development began in this world. God created human beings in pairs consisting of men and women, nations and tribes whose purpose is to get to know one another. ${ }^{5}$ The saying goes "Do not know then do not love, do not love, do not love, do not love so do not marry", Marriage ${ }^{6}$ for mankind is something that is very sacred and has a sacred purpose, in accordance with the provisions stipulated religious shari'ah. ${ }^{7}$ Marriage comes from the word marriage (نكح) which according to language means to gather and use for the meaning of intercourse (wathi). ${ }^{8}$ Or in another sense al-Nikah means al-Wathi and al-Dammu Wa al-Tadakhul Or also interpreted as merging

1 Indonesian Ministry of Religion, al-Qur'an Translation, verse 1 (Jakarta: The Indonesian Ministry of Religion, 2005).144

2 Indonesian Ministry of Religion, al-Qur'an Translation, verse 12 (Jakarta: The Indonesian Ministry of Religion, 2005).222

3 Indonesian Ministry of Religion, al-Qur'an Translation, Verse 21 (Jakarta: The Indonesian Ministry of Religion, 2005).644

4 Nurhadi, Analysis of the Concept of the Samara Family in Law No. 1 of 1974 concerning Marriage and KHI according to Islamic Law (Pekanbaru: STAILe, 2017), 1.

5 Indonesian Ministry of Religion, al-Qur'an Translation, verse 13 (Jakarta: The Indonesian Ministry of Religion, 2005), 847.

6 The use of the word "Marriage" is likened to "Marriage", intended to facilitate the compiler because many references use both words with the same purpose

7 Mohammad Asnawi, Marriage in Discussion and Difference, vol. 1st (Yogyakarta: Darussalam, 2004), 19.

${ }^{8}$ Abdul Rohman Ghazali, Fiqh Munakahat (Jakarta: Kencana, 2006), 7. 
and mixing. ${ }^{9}$ Moving on from the etymological meaning above, marriage in terminology (term) is marriage which means a contract between the male and female guardian, which is why the body relationship becomes halal.10 In addition, marriage can also be interpreted 11 as a contract stipulated by shara 'to allow fun between men and women and justify the fun of women and men. ${ }^{12}$

While marriage according to the scholars there are several opinions among them:

First, according to Wahbah Al-Zuhaili marriage is a contract that allows the occurrence of Al-Istimta 'with a woman or do wathi and gather as long as the woman is not a woman who is forbidden either because of hereditary or hereditary causes. ${ }^{13}$

Second, Abu Yahya Zakariya Al-Anshary defines; Marriage according to the term syara 'is a contract containing legal provisions regarding sexual relations with marital lafadz or with words that are meaningful to it. ${ }^{14}$

Sixth, the Hanabilah Group defines marriage as; Marriage is a contract by using lafadz lafadz marriage or tazwij to allow benefits, have fun with women. ${ }^{15}$

From the above understanding Marriage contains aspects of the legal consequences of mutual rights and obligations, and aims to hold relationships based on help-help, because marriage is the implementation of religious shari'ah, then there is a purpose and purpose that is to expect the pleasure of Allah Almighty. ${ }^{16}$

The purpose of marriage according to Islam is to fulfill religious guidelines in order to establish a harmonious, prosperous and happy family. Harmonious in using the rights and obligations of family members, prosperity means the creation of physical and spiritual tranquility due to the fulfillment of the necessities of life and birth, so that happiness is

${ }^{9}$ Shaykh Hasan Ayyub, Figh of the family (Jakarta: Pustaka Al-Kautsar, t.t.), 29. 1029.

${ }^{11}$ Indonesian Ministry of Religion, al-Qur'an Translation, verse 6 (Jakarta: The Indonesian Ministry of Religion, 2005).

${ }_{12}$ Analysis of the Concept of the Samara Family in Law No. 1 of 1974 concerning Marriage and KHI according to Islamic Law, 2.

13 Amiur Nuruddin dan Azhari Akmal Tarigan, Islamic Law in Indonesia (Jakarta: Kencana, 2006), 38.

${ }^{14}$ Figh Munakahat, 8.

${ }^{15}$ Djamaan Nur, Fiqih Munakahat (Semarang: Dimas Semarang, 1993), 2.

162. 
created, namely love between family members. ${ }^{17}$ In Chapter II KHI about the basics of marriage article (3) it is mentioned that marriage aims to realize a sakinah home life, mawaddah wa rahmah. ${ }^{18}$ Sakinah is able to solve all problems that arise well, so as to create a calm. ${ }^{19}$ Mawaddah according to Ibrahim bin Umar Al-Baihaqy, an interpreter from Egypt, mawaddah is love, a heart that mawaddah will not break the fabric of affection. Rahmah according to Quraysh Shihab in his book "Grounding the Qur'an" interpreted it with a psychological condition that arises in the heart due to witnessing helplessness. Husband and wife will seriously do empowerment for the sake of bringing good for their partners, as well as rejecting everything that disturbs and overwhelms them, thus encouraging those concerned to empower them. ${ }^{20}$ Imam Ghazali in the book of Ihya'ulumiddin about the benefits of getting married, then the purpose of marriage can be developed into five, namely:

1. Obtaining and continuing offspring

2. Fulfill human lust to channel his lusts and shed his affection.

3. Fulfill religious vocation, protect yourself from crime and damage.

4. Foster seriousness to be responsible for accepting rights and obligations as well as seriously obtaining halal assets.

5. Building a household to form a society based on love and affection. ${ }^{21}$

Housekeeping is a demand of human nature as a social creature. Muslim family or household is the most important institution in the life of Muslims in general and Islamic charity management in particular. This is all due to the large role played by the family, which is to print and grow the future generations, pillars supporting the building of the Ummah and a savior shield for the country. ${ }^{22}$

So it is no exaggeration to say that the family is the initial foundation of the building of society and nation. Therefore, the safety and purity of the household is a determining factor for the safety and purity of the

17 Baca Abdul Rahman Abdul Kareem al-Sheha, (Islam is The Religion of Peace), http://ww1.islamland.org/?sub1=d1964f9c-fc38-11e8-ba29-00c4d6d790d4, t.t., 22.

18 Baca Abdul Rahman Abdul Kareem al-Sheha, (Islam is The Religion of Peace), http://ww1.islamland.org/?sub1=d1964f9c-fc38-11e8-ba29-00c4d6d790d4, 78 .

19 Analysis of the Concept of the Samara Family in Law No. 1 of 1974 concerning Marriage and KHI according to Islamic Law, 5.

${ }^{20}$ Khudzaifah Al-Jurjani, The Most Absolute Marriage of Marriage That Is Furious by God (Jombang: Cross Media, t.t.), 110.

${ }^{21} 112$.

${ }^{22}$ Musthafa Mashhur, Qudwah on Da'wah Street (Jakarta: Citra Islami Press, 1999), 71. 
community, as well as determining the strength, robustness, and safety of state buildings. ${ }^{23}$ From this it can be concluded that if the construction of a household is destroyed then as a logical consequence the community and the state will certainly also be destroyed. ${ }^{24}$

Then every existence of a group or group of people consisting of two or more individuals, can not help, surely the existence of a leader or someone who has the authority to regulate and simultaneously oversee other individuals (but it does not mean like the existence of superiors and subordinates). ${ }^{25}$

Likewise, a family, because the so-called family is a minimum consisting of a husband and a wife who subsequently give birth to children and children give birth to children onwards. ${ }^{26}$ So, it should be in a family that there is also a need for a family leader whose job is to guide and direct at the same time meet the needs of both the nature and spiritual nature of the household in order to form a sure family, mawaddah wa rahmah. ${ }^{27}$ In the Qur'an it is stated that the husband or father who has the task of leading his family.

As a family leader, a husband or father has a duty and obligation that is not easy to lead the family. He is the person who is responsible for each individual and what is related to him in the family, whether related to the Ahmadiyya, Ruhiyah, or his aqliyah. ${ }^{28}$ Associated with the Ahmadiyya or that is identical with outward needs, such as clothing, food, shelter, or social needs such as the need to interact with others and so forth. ${ }^{29}$ While the needs associated with Ruhiyah such as religious needs, aqidah needs or

${ }^{23}$ Analysis of the Concept of the Samara Family in Law No. 1 of 1974 concerning Marriage and KHI according to Islamic Law, 6.

2472.

${ }^{25}$ Miftahul Ulum, Concept of Sakinah Family According to Tablighi Jamaah in the Perspective of Islamic Law (Cirebon: Ministry of Religion of the Republic of Indonesia Institute of State Islamic Religion (IAIN) Sheikh Nurjati, 2012), 3; Aminuddin, Da'wah and Family Strengthening (Kendari: State Islamic Institute, t.t.), 14. 2001), 7 .

26 Maimunah Hasan, Muslim Household (Yogyakarta: Bintang Cemerlang,

27 Analysis of the Concept of the Samara Family in Law No. 1 of 1974 concerning Marriage and KHI according to Islamic Law, 7.

${ }^{28}$ Qudwah on $D a^{\prime}$ wah Street, 73.

29 Analysis of the Concept of the Samara Family in Law No. 1 of 1974 concerning Marriage and KHI according to Islamic Law, 8. 
the needs of monotheism, and so on. Then next is the need that is aqliyah namely the need for education. ${ }^{30}$

But of all the needs mentioned above, Ruhiyah's needs are the most important. ${ }^{31}$ Namely anything related to Islamic Aqeedah. Because this problem continues until later life in the hereafter. ${ }^{32}$

Apart from being a husband and / or father who has responsibility for the family he leads, men as a Muslim also have a task that is no less important and is the main task of every Muslim or believer who is married, that is maintaining the integrity of his household until the drop the last blood, because the jihad of a husband or father is to maintain the integrity of his household from riots, problems and twists and turns of life not to end up on the court court with the judge's decision on the status of divorce, which is certainly a victim of children. 33 The main purpose of marriage is to form a happy family full of peace of love and compassion. Allah says Surah Ar-Rum 21:

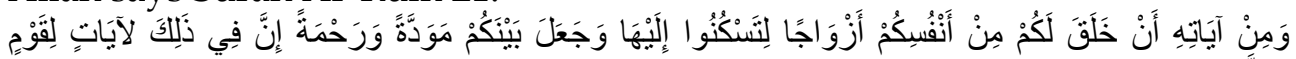

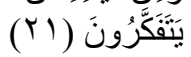

Meaning: And among the signs of His power is that He created for you wives of your own kind, so that you are inclined and feel at ease with him, and He made you with love and affection. Surely in that there really are signs for people who think. ${ }^{34}$

This verse mandates all human beings, especially Muslims, that the creation of a wife for a husband is so that the husband can live peacefully together in fostering the family. The peace of a husband in fostering with his wife can be achieved if between the two there is mutual cooperation that is harmonious, harmonious and balanced. Each cannot be unrequited, as a real man, a husband would certainly not feel at ease, if his wife had done the best for the happiness of the husband, but the husband was unable to provide happiness to his wife. And vice versa, the new husband will feel at ease, if he is able to make his wife happy and his wife is able to provide balanced services for her husband's happiness. Both parties can love and love each other, mutual understanding between one another in

30 Concept of Sakinah Family According to Tablighi Jamaah in the Perspective of Islamic Law, 7.

${ }^{31}$ Qudwah on $D a^{\prime}$ wah Street, 50.

32 Indonesian Ministry of Religion, al-Qur'an Translation, 2005.951

${ }_{33}$ Cole, K, Accompanying children in facing parental divorce (Jakarta: PT. Prestasi Pustaka Raya, 2004), 27.

${ }^{34}$ Indonesian Ministry of Religion, al-Qur'an Translation, 2005.644 
accordance with their respective positions for the sake of achieving a family that is sure, mawaddah, warahmah. ${ }^{35}$

But in building a family is not as smooth as what we imagine, because there are many conflicts in the household as a test in building a household. Ironically, there is a household that goes on not because of harmony but because of thinking and fighting for the child, thinking about parents and family, thinking about shame and thinking about a career in work. All passed with a depressed heart. So it is not surprising that the infidelity of infidelity is rife. But not a few that led to divorce. 36

Divorce rates in Indonesia are still the highest in Asia. From 2009 to 2016, the increase in divorce rate has increased by 16-20 percent. In 2015, there were 40 divorce hearings every hour or about 340,000 more divorce claims. ${ }^{37}$ As a result children are the victims. They are mentally injured, feel insecure and often do not get enough attention and affection from their parents.

Divorce in Islam is permissible, but Allah does not like it. Because in the end the ones who suffer the most are children. In addition to a survey at the Belitar Children's Penitentiary, 30 percent of the children of perpetrators of crimes in the prison had a broken home background.

Basically the factors that cause divorce are very unique and complex and each family is different from one another. The factors that lead to divorce in the household can be pointed out by the writer is: 38

1. Economic Factors.

2. Early marriage.

3. Religious factors

4. Factors of disharmony in the household.

Strangely there are households that have long been fostered divorced in old age, and some even divorced at the age of corn. Divorce cases are not only among ordinary people but also among the elite, officials, scientists of wealthy people who are already well-established in the outward appearance. But what actually happens in the household so the divorce rate is increasing. This is the importance of analysis and research so that this

${ }^{35}$ Analysis of the Concept of the Samara Family in Law No. 1 of 1974 concerning Marriage and KHI according to Islamic Law, 9.

${ }^{36}$ Analysis of the Concept of the Samara Family in Law No. 1 of 1974 concerning Marriage and KHI according to Islamic Law.

37 Ahmad Rafiq, "National Seminar, "About Family Law Polemic in Indonesia During the Industrial Revolution 4.0" (Uin Suska Pekanbaru, t.t.), 2018.

38 Analysis of the Concept of the Samara Family in Law No. 1 of 1974 concerning Marriage and KHI according to Islamic Law, 12. 
problem can be solved at least minimizing divorce. Because there are still many who do not understand the meaning and purpose of a marriage as attached in the Ar-Rum letter (30): 21. And Law Number 1 of 1974 concerning marriage for the whole Indonesian people. Whereas specifically Muslims are reinterpreted by the compilation of Islamic law (KHI) Some of us still understand superficially even do not know how to achieve the goal of marriage, especially forming a sakinah family, so what happens then marriage does not have the essence as intended by the Koran 's itself. Not surprisingly, because of this many circles of Islamic thinkers or scholars try to make a formula or concept about the sakinah family. ${ }^{39}$

Departing from this, the writer is interested in expressing one of the thinkers or scholars who formulated the concept of the sakinah family, M. Quraish Shihab. This interest is due to several things, among them. First, M. Quraish Shihab is known as an interpreter in Indonesia who has relatively the best education among other interpreters of the Koran so that his work is a new standard for the study of the Koran used in Indonesia. Second, the work of M. Quraish Shihab written not only for scholars but also ordinary people. Third, he is an Indonesian who knows the social aspects of the Indonesian people themselves. Fourth, the thinking is more Indonesian and modern than the others as far as the author knows, of course his thoughts are in harmony with the relations of family relations in our country. Fifth, directly or indirectly, he was involved in politics so he was once the Minister of Religion, rector of UIN Syarif Hidayatullah Jakarta and also other positions..$^{40}$ Sixth, as far as the author knows, no one has written about the Maqashid al-Shari'ah Review of the Sakinah M. Qurais Shihab Family Concept in Tafsir al-Mishbah.

\section{B. Biography Of Muhammad Quraish Shihab}

M. Quraish Shihab was born on February 16, 1944 in Rappang, South Sulawesi. He was one of the sons of Abdurrahman Shihab (1905-1986), a self-employed entrepreneur and scholar who was quite popular. Especially among Muslim intellectuals. His father was a professor in the field of interpretation, and had served as Chancellor at IAIN Alauddin Makassar. $\mathrm{He}$ is also one of the initiators of the founding of UMI (Indonesian Muslim University), a leading private university in Makassar. ${ }^{41}$

3920 .

40 Salamah Noorhidayati, "Women's Leadership in Islam: Study of the Thought of the Interpretation of M. Quraish Shihab," Al-tahrir Vol. 5, no. No. 1 (Januari 2005): 8-9.

41 Arif Subhan, "Grounded Tafsir," Tsaqafah Vol. 1, no. No. 3 (2003); M. Quraish Shihab, Grounding the Qur'an (Bandung: Mizan, 1992), 14. 


\section{Education}

His educational history as far as I know in various references is as follows:

a. SD to $2 \mathrm{SMP}$ in South Sulawesi,

b. Pesantren Darul Hadis al-Faqihiyah, Malang, East Java, 1956-1958

c. Second class of Al-Azhar Egyptian Ahmadiyya, 1958-1963

d. S1, Faculty of Usuluddin, Department of Interpretation and Hadith, Al-Azhar University, Egypt, 1963-1967

e. S2, Faculty of Usuluddin, Department of Interpretation and Hadith, Al-Azhar University, Egypt, 1967-1969

f. S3, Qur'anic Interpretation Study, Al-Azhar University, Egypt, 19801982.

1984 was the second phase of the new phase for Quraish Shihab to continue his career. For this reason he moved from IAIN Makassar to the Faculty of Usuluddin at IAIN Jakarta. Here he actively taught the field of Tafsir and Ulum Al-Quran in the S1, S2 and S3 Programs until 1998. In addition to carrying out his main duties as a lecturer, he was also trusted to hold positions as Chancellor of IAIN Jakarta for two periods (1992-1996 and 1997- 1998). After that he was trusted to hold the position of Minister of Religion for approximately two months in early 1998, until then he was appointed as Extraordinary and Plenipotentiary Ambassador of the Republic of Indonesia to the Arab Republic of Egypt and concurrently the Republic of Djibouti based in Cairo. ${ }^{42}$

\section{Career}

His careers as long as I know in various references are as follows:

a. Lecturer at IAIN Alauddin, Makassar, South Sulawesi

b. Vice Chancellor for Academic and Student Affairs at IAIN Alauddin, Makassar, South Sulawesi

c. Coordinator of Private Universities Region VII of Eastern Indonesia,

d. Assistant Chief of the Eastern Indonesian Police in the Mental Development Sector

e. Lecturer, Faculty of Ushuluddin and Faculty of Post-graduate IAIN (UIN) Syarif Hidayatullah, Jakarta, 1984

f. Chairperson of the Indonesian Ulema Council (MUI) Center, since 1984

42 Muhammad Quraish Shihab, "Wikipedia Indonesian, Free Encyclopedia," diakses 12 Juni 2019, http:/ /id.wikipedia.org/wiki/Muhammad_Quraish_Shihab. 
g. Member of the Lajnah Pentashbih al-Qur'an at the Ministry of Religion, since 1989

h. Member of the National Education Advisory Board, since 1989

i. Chancellor of the Jakarta IAIN for two periods, 1992-1996, and 19971998

j. Minister of Religion of the Republic of Indonesia, 1998

k. Ambassador Extraordinary and Plenipotentiary of the Republic of Indonesia for the Arab Republic - Egypt

1. Director of the Al-Quran Study Center, Prof. Dr. M. Quraish Shihab MA, 2004.

\section{Works of M. Quraish Shihab}

As an expert on interpreting Indonesia has a role, and a major contribution in enriching the treasures of Islamic scholarship, this is evidenced by some of his works that can be collected authors, among others:43

1) Al-Qur'an's Insights: Maudhu's Interpretation of Various Problems of People (Bandung: Mizan, 1996).

2) Grounding the Qur'an: the function and role of revelation in people's lives (Bandung: Mizan, 1998).

3) Divine Dishes Tahlil Verses (Jakarta: Lantern hearts, 1997).

4) Tafsir al-Qur`an al-Kari Tafsir on Short Letters Based on the Order of the Revelation of Revelation (Bandung: Pustaka Hidayah, 1997).

5) Interpretation of Al-Mishbah: Messages, Impressions, and Harmony of the Qur'an (Jakarta: Lentera Hati, 2000).

6) Fatwas of M. Quraish Shihab Regarding the Qur'anic Interpretation.

7) Tafsir al-Manar.

8) Lentera Hati Hati (Story of Life) and Life Wisdom, this book contains selected writings of M. Quraish Shihab, which was published in the daily Pelita, from 1990 to early 1993.

9) Women, from love to sex, from mut'ah marriage to sunnah marriage.

10) Gems for my son; Message of the Qur'an for the bride and groom.

11) Rules of Interpretation.

12) Disclosing the Divine Veil: Asma al-Husna in the Perspective of the Qur'an, (Jakarta: Lentera Hati, 2001).

13) Mystique, Sex and Worship (Jakarta: Republika, 2004).

14) Religious Logic; Position of Revelation and the Boundaries of Intellect in Islam, (Jakarta: Lentera Hati, 2005). .

43 Ishlah Gusmian, Khazanah Tafsir Indonesia from Hermeneutics to Ideology (Jakarta: Teraju, 2003), 98-99. 
15) Miracles of the Qur'an (Bandung: Mizan, 2014).

16) 40 Selected Qudsi Hadiths (Jakarta: Lentera Hati).

17) Doing business with God; Tips to be a successful businessman in the afterlife (Jakarta: Lentera Hati).

18) M. Quraish Shihab Answering; 1001 Islamic Questions You Should Know (Jakarta: Lentera Hati, 2008)

19) Daily Prayer with M. Quraish Shihab (Jakarta: Lentera Hati, August 2009).

20) Smooth and Invisible Series; Jinn in the Koran (Jakarta: Lantern of the Heart).

21) Smooth and Invisible Series; Angels in the Qur'an (Jakarta: Heart Lanterns

22) Smooth and Invisible Series; Satan in the Koran (Jakarta: Lantern of the Heart

23) M. Quraish Shihab Answering; 101 Problem Women You Need to Know (Jakarta: Lentera Hati, March 2010

24) Critical Study of Tafsir al-Manar (Bandung: Pustaka Hidayah, 1996

25) Insight into the Qur'an; Maudhu'i's Interpretation of Various People's Problems (Bandung: Mizan, 1996

26) Tafsir al-Qur'an (Bandung: Pustaka Hidayah, 1997

27) Glimmer of Divine Light; Living Together with the Qur'an (Bandung; Mizan, 1999

28) Divine Dish, Tafsir Tahlili Verses (Jakarta: Lentara Heart, 1999).

29) Road to Eternity (Jakarta: Lentera Hati, 2000).

30) Tafsir Al-Mishbah; Message, Impression, and Harmony of the Qur'an (15 Volume, Jakarta: Lentera Hati, 2003).

31) Picking up Death; Provision of Journey to Allah SWT. (Jakarta: Lentera Hati, 2003).

32) Headscarves of Muslim Women's Clothing; in the Views of Contemporary Scholars and Scholars (Jakarta: Lentera Hati, 2004).

33) He is everywhere; God's Hand Behind Every Phenomenon (Jakarta: Lentera Hati, 2004).

34) Women (Jakarta: Lentera Hati, 2005).

35) Religious Logic; Position of Revelation \& Boundaries of Intellect in Islam (Jakarta: Lentera Hati, 2005).

36) The rationality of the Koran; Critical Study of Tafsir al-Manar (Jakarta: Lentera Hati, 2006).

37) Sowing Divine Messages; the Qur'an and the Dynamics of Community Life (Jakarta: Lentera Hati, 2006).

38) Insight into the Qur'an about Dhikr and Prayer (Jakarta: Lentera Hati, 2006). 
39) Asmâ 'al-Husna; In the Al-Qur'an Perspective (4 books in 1 box) (Jakarta: Lentera Hati).

40) Sunnah-Shia Join Hands! Is it possible?; Study of Concept.

41) Doctrine and Thought (Jakarta: Lentera Hati, March 2007).

42) Al-Lubab; The Meanings, Objectives and Lessons of al-Fatiha and Juz 'Amma (Jakarta: Lentera Hati, August 2008).

43) 43) Al-Qur'an and Its Meaning; The Meaning Translation was compiled by M. Quraish Shihab (Jakarta: Lentera Hati, August 2010).

44) Earthing al-Qur'an Volume 2; Enabling Revelation in Life (Jakarta: Lentera Hati, February 2011).

45) Reading the Sirah of the Prophet Muhammad PBUH, in the spotlight of the Qur'an and Sahih Hadith (Jakarta: Lentera Hati, June 2011).

46) Du'a al-Asmâ 'al-Husna (Prayers that Allah likes) (Jakarta: Lantern of the Heart, July 2011).

47) Tafir Al-Lubab; The Meanings, Objectives, and Lessons of the Surahs of the Qur'an (Boxset consists of 4 books) (Jakarta: Lentera Hati, July 2012).

\section{The Influence of Thought of M. Quraish Shihab}

As is known, that M. Quraish Shihab is a leading scholar of interpretation in this country. His monumental work in the field of interpretation is published and is a reference for Qur'anic scholars. Among the thoughts of M. Quraish Shihab, can be seen from a variety of his works, for example about Islamic law and education. But this time M. Quraish Shihab not only reviewed the contents of the Koran in harmony with current phenomena, he began to enter the field of Islamic law by responding to the problems of Islamic law, especially those in Indonesia. His work which the author considers as part of its study in Islamic law which is now also the best-selling book and published by Lentera Hati is "M. Qurasih Shihab Answering 1001 Islamic Questions You Need to Know ". This book amounts to 929 pages, and the author classifies it into a study of Islamic law because of its contents which are the result of questions and answers between the Muslim and non-Muslim subjects with M. Quraish Shihab, or the results of his fatwa regarding issues of worship, al-Qur'an and Hadith, mu'amalah, and religious insight.44 In addition to the book above, a study of Islamic law conducted by Quraish Shihab with a question and answer method is also a "Guide to Fasting with the Qurasih Shihab" published by the republika publisher as thick as 176 pages.

44 M. Quraish Shihab, Answering 1001 Islamic Questions You Should Know (Jakarta: Lentera Hati, 2008), 8-25. 
His writing is trying to enter into the thinking space of the laity, unlike his writings in the field of al-Qur'an which is only an intellectual study of Islam. However, after reading his writings in the field of Islamic law, it was found that the answers were not very clear even as if inviting the sipinya to do talfîq. An example is the question of understanding the kुhatîb who does not faşih reading the Qur'an. In this case, he presented the opinions of the Imams, such as Imâm alŚâfi'î dan Imâm Abû Hanîfah tentang syarat-syarat bagi sahnya ķuțbah jum'at. ${ }^{45}$

\section{Discussion}

1. Analysis of the Concept of the Sakinah Family in the Maqashid Sharia Review in the Book of Tafsir Al-Mishbah by Muhammad Quraish Shihab

Analyzing and delving into the contents of the Al-Mishbah interpretation written by Muhammad Quraish Shihab, especially verses about the sakinah family, then several points of thought can be taken in the review of sharia maqashid which can be used as a basis of thought in formulating the concept of sakinah family in sharia maqashid frames. In order to make it easy to conclude the meaning in a concise but congressive manner, the researcher presents the famous expressions in the community: "Do not know, do not love, do not love, then do not love, do not love, so do not marry, do not marry, do not become family sakinah ". The translation of this expression is implicit in the concept of the sakinah family in the interpretation of Al-Misbah, including:

a. Sakinah family is a marriage that means to unite the soul (mind) and body (birth) or heart and soul (body) or soul and body. ${ }^{46}$ The meaning that marriage is not only unites or falsifies or marries between man and woman to become husband and wife, both of which have become a destiny that has been destined by God, but the nature and purpose of marriage is to unite love, affection and needs of both, outwardly and inwardly, both physically, physically, physically or mentally, mentally, spiritually or spiritually. This means that the Sharia family maqasyid is marrying Adam's grandchildren with his partner physically and mentally. Illustration unites both hearts and bodies both, namely male and female, so that if they are united both physically and mentally, God willing, a sakinah family will be realized in their second family life.

4525.

46 Muhammad Qurais Shihab, Tafsir Al-Misbah (Jakarta: Lentera Ilmu, 2008), 223. 
b. Sakinah family is a marriage that brings physical and spiritual peace. If the marriage is to unite the physical body and soul, then the marriage has a purpose so that both Sakinah is born and the mind is both. Maqasyid syariah family sakinah will bring peace and tranquility of the heart and soul of the husband and wife, if both are united in one unity that cannot be separated, mutual need and complement the joints of the life of the world and the hereafter. This marriage will give birth to calmness and peace (sakinah) in the household, so that between husband and wife are like one body that has half the body without the other, meaning that the husband lives half body if without wife, and vice versa wife half body if without husband.

c. Sakinah family is a family that knows each other physically and mentally from each other (husband and wife). Before marriage, then in Islamic Shari'ah it is recommended to ta'aruf (know each other physically and mentally) according to what is intended. This is done so that there is no saying goes to buy a cat in a sack. Even though it is a woman, the prospective husband must know more deeply the origin of his future wife, education, character, nature, occupation, knowledge and religion. Likewise, on the contrary, the prospective wife to the prospective husband, even though it is a man, of course, must know how exactly the priest will bring him into his household mahligai so that he does not regret it because it is not realized by a sakinah family. After getting to know each other, it is also advisable in the Shari'a to propose it (ask for it) by opening cards to each other in front of the two big families of the prospective husband and wife, because basically marriage also unites two large families. After completing the two of them together, then they will continue to plan their marriage contract to fulfill their dreams of reaching a sakinah family.

d. Sakinah family is a family that loves each other physically and mentally, with each other (husband and wife). Introducing is the beginning of love and love will flourish and blossom. Then the next stage if you already know will bring empathy and desire to have and together in a container of love to sow love and harvest sakinah in the household. Introduction gives birth to affection, it will lead the soul and heart to complement and possess each other, therefore it is important that both husband and wife couple love each other physically and mentally, without exception if there are later thorns and steep cliffs that must be passed, by loving each other it will feel the pain and horror of living domestic life, with which the thorn feels therapeutic and the gut feels guts, this will deliver a household full of calm and serenity (sakinah). 
e. Sakinah family is a family who love each other physically and mentally, and each other (husband and wife) and demands loyalty. Introducing the beginning of calm, compassion and loving the beginning of love and the desire to be together forever with the permission of God. love and affection is the greatest gift of God to mankind and even to all living creatures including animals and plants. Love and affection is a pair, there must be a place to pour out love and affection. Love can not stand alone without a partner, usually when meeting with the opposite sex who initially only knew, it will be a shame, which initially only love will fall in love and sink into the sea of love (mahabbah). Love is human nature, some are loved, some are loved, some are loving, some are loving, all of which have to be done with all your heart and soul, so that love is eternal until death, not halfhearted love or love to hurt. A deep love will be realized if love is based on obedience to God. Do not let love for beings exceeds their love for God, because in fact God is all-loving and loving. True love is love that is sacred because it carries out the divine command of rabbi Allah. Even in a hadith it is stated that a person of faith will not get the sweetness of faith before Allah and his Messenger are loved and loved more than his lover (husband or wife even children and parents-inlaw). It means that the true love that is brought to death is love because of Allah and carries out according to the guidance of the Shari'a of God that the Prophet Muhammad brought. When love is due to Allah, then God will provide peace and peace in the household, this becomes asbab the realization of a sakinah family in his life. Love brings obedience, love brings submission and obedience to God's commands. The meaning of being loved and loved (husband or wife) brings him to be loved and loved by God Almighty.

f. Sakinah families must channel each other biologically and get offspring. Love is beautiful, but beauty will not be enjoyed without being channeled to the loved one, then it becomes the basic basis of human being given reason and lust, love and affection must be channeled in the form of biological relationships, both physically and spiritually. The biological association will spontaneously shed seeds in a noble container, a love jug called the uterus. In this womb the seeds of love will proceed according to their sunatullah and will be born into the world after 9 months and 10 days, which are called offspring or subordinates of the outlet of love from both husband and wife. When the fruit of love or heart is born, because the relationship is done wholeheartedly, also called a child, then automatically feeling happy, calm, happy and peaceful envelop both husband and wife, this term is 
called a quiet life or happy life, which in Arabic is home ladder sakinah mawaddah warahmah. How is it possible for a household to be happy or confident without any descendants in their lives. Sometimes happiness cannot be paid for with material wealth or throne, it is mostly without wealth and luxurious throne, but if there is a child whose offspring results from their love will bring happiness and peace or peace in the household. The evidence from this discussion has been studied by researchers in the previous discussion.

g. Sakinah family comes from all family members (husband and wife and children). Still continuing the previous sub discussion study, that husband and wife in order to get sakinah and calm must have to channel their biological instincts as human nature is created to have lust. When that happens, with God's permission the offspring will be born as a result of husband and wife love in the household. But that sometimes is not necessarily in the long journey of marriage will always be sure and happy. Therefore both parents as a form of responsibility to maintain peace and peace and sakinah in domestic life, must transmit children's devotion to their parents. The love of parents to their children must be reciprocated with the love of children to their parents, this will arise if both parents provide education and teaching and advice on the importance of doing good and serving both parents. If a household finds its children doing good and filial and having good morals to both parents, then this will maintain a sense of happiness and peace or sakinah in family life. The key to all of this is to teach children the knowledge of religion and religious observance, God willing, the family will sakinah mawaddah warahmah.

h. Sakinah family is able to unite two large families of husband and wife. Marriage is to unite two people who know each other, love each other and love each other physically and mentally, but further than that the sharia maqasyid of marriage is uniting two large families of married couples. It feels happiness will unravel over time, even if husband and wife and children are pious and pious, if the existence of the family is not loved and loved by both parents, parents-in-law, brother-in-law, brother and sister-in-law. Therefore maqasyid sakinah family globally is uniting a large family of husband and wife. The unity of both sides of the extended family will add to and enrich the level of peace and happiness in the household, this will be a lesson and uswah qudwah for all members of the extended family of both parties, so that they always seek and reach and reach the sakinah family mahligai in the household, as which occurred one of the members of the extended family. Sakinah in a big family is important, but don't sacrifice sakinah 
in a nuclear family. Some cases in the community that occur, both partners are willing to sacrifice the happiness of this household, for the sake of a large family, this is very inappropriate and needs special guidance to deal with this problem. So that a household does not become a victim of ignorance (ignorance). There are sensitive things in the case of large families, namely parents and in-laws, so this is a special study of filial piety and doing good to parents and in-laws. Below, the researcher tries to illustrate sakinah in a large family:

i. Mawaddah and warahmah sakinah families are sourced from the heart (heart), then radiate outward in the form of activities (husband and wife), both individuals and communities. Knowing each other is not enough if you only know your potential lover without knowing your soul and heart, then before you know someone else (the opposite sex), then know your own soul and heart, because your heart will bring peace and serenity (sakinah). Love one another is not enough, if only dear to his lover, then love the merciful God, because the heart is the center of everything, then recognize the merciful God, God willing, God will give his affection in someone's heart, so with a heart full of love this is someone will love someone else (his lover) with all his heart, this will bring happiness and peace (sakinah). While love will come alone if someone already knows and loves, but mutual love and love is not enough, if love does not come from the heart, then it is love that turns back and forth, and love God who bestows love in one's heart. Therefore, know God, love God and love God, then God willing, God will leave love and affection in your heart, so that you can love something wholeheartedly, love your heart, know it wholeheartedly. If that happens automatically the light of calmness, love and affection will radiate within, both words, attitudes and behavior, all of which are always weighed by the heart. If the rays of light have covered the whole body and soul then it becomes evidence that the birth and the stone are already mawaddah warahmah. Because all three will be obtained if it starts from a pure clean heart and radiates ma'rifatullah (know Allah), muqarabatullah (love for Allah) and mahabbatullah (love for Allah). This is the origin of the sakinah family, which must start from the heart of each family member, both the nuclear family (husband and wife and children) and extended family (parents-in-law and relatives and in-laws). This is what will deliver a family sakinah mawaddah warahmah until the end of life. While at the end of his life he will leave the world with husnul khatimah (dying because of Allah to meet the God he knows, loves and loves). 
j. Sakinah family strongly supports the effectiveness of worship of God. Self-introduction to the heart and to God, unfortunately the self into the heart and God, and love for the heart and God. Then someone has purified and cleaned his heart. If the heart is clean and pure then the heart is easily occupied and remembers God. This means that a sakinah family that starts from a sakinah heart will make the worship of a servant to Allah swt effective. Every worship is performed with calmness and peace and peace only for Allah alone without the others. The deepest meaning of the sakinah family or the sharia maqasyid is the sakinah minannas and sakinah minallah, in the language of the Koran the hablumminannas are good and the hablumminallah is good, that is a person who is truly happy and sakinah in his life, not only in the world of bah.

From the explanation above, the essence of this discussion is that the sharia maqasyid from the concept of sakinah family according to Muhammad Quraish Shihab in the interpretation of Al-Mishbah is mahabbatullah (love of God). Love (mawaddah) is a tree that thrives in the heart. The root is humility to the lover (warahmah), the trunk is recognition of him, the branches are fear of God and creatures so that no one stains him, the leaves are shyness humiliating and humiliated, the fruit is the unity of the heart that gives birth to cooperation, the interest is mutual keep the honor and close the disgrace of others, the seeds are calm (sakinah), while the water that sprinkles them is to remember and mention his name.

To make it easier for readers to understand this study, the researcher will make an illustration of the steps of the sakinah family concept according to Muhammad Quraish Shihah in his interpretation of AlMishbah

In order to realize the true sakinah family from the time after the marriage contract to the children and grandchildren and the end of life, it must start from the heart of his own heart, then channeled to the hearts of his life partner, so that the heart of his life partner, then taught to the hearts of his offspring, so that his children have hearts sakinah, then preached and devoted to the care of large families, namely parents, parents-in-law, siblings and in-laws, with their caution sakinah, then formed a sakinah large family, this will become a community in the social environment, if all big families are sure, then a community or village group or even the State will become baldatun thayyibatun warabbun ghafur. Maybe the illustration of the steps of the Sakinah family above is still quite difficult to understand, so the researchers made a sakinah heart wave scheme. Pay attention and examine the following illustration: 
Sakinah arises from the soul and heart of an individual person, rises to body and body, radiates into the hearts of married couples, rises again illuminates their children, rises again illuminates family members from the husband and wife. Sakinah hearts are obtained by obedience and zikrullah (remember Allah). So to get a truly sakinah family, invite all elements of family members to obey the religion and submit to the Shari'a of Allah. So that every family member is obedient to religion, then he must study religion and live it, then practice it, this is in accordance with the concept of the surahah surahah family of At-Tahrim verse 6 in the previous discussion above.

\section{Relevance of the Sakinah Qurais Shihab Family Concept in the Development of Family Law in Indonesia}

The speed of community participation in organizing a marriage contract justifies the form of adultery and the high number of divorces that is incompatible with the motto of marriage, namely forming a sakinah mawaddah warahmah family and the principle of marriage law number 1 of 1974 concerning marriage, which has the principle of complicating divorce and facilitating marriage. with the marriage isbats in court (PA).

The concept of maqasyid syariah family of sakinah Muhammad Quraish Shiab in the book of his interpretation of Al-Misbah which says that the sakinah family must be cultivated and fought for, not as long as spoken. The form of effort and endeavor in realizing it must start from the hearts of each married couple and family members (children) and extended family members (parents, parents-in-law, siblings and in-laws), because it is not uncommon for members of this extended family to be a factor the cause of the high divorce rate, due to too much interference with the child, sibling and brother-in-law's household. Both concepts are still very relevant and even very relevant to the situation of the problematic conditions of family law in Indonesia which are increasingly increasing and problematic.

The solution of the existing problems, it is considered necessary by the government in this case the ministry of religion to establish a sakinah family counseling institution, both premarital or post-marital, even when a marriage dispute is in progress (the judicial process). Also increasing the number of mediators in the religious court, before the evidentiary and testimony hearing, the marriage litigants, both defendants and plaintiffs, both divorced and divorce requests, must be mediated in such a way and avoided or made it difficult to continue the trial for litigants in the PA (court religion). The existence of mediators who will mediate litigants in the PA will reduce the divorce rate in the community. With the decline in 
divorce rate means the percentage of the realization of sakinah families is increasing, this is the hope of researchers through this paper.

According to the researcher sakinah family concept Muhammad Quraish Shihab in the Al-Mishbah interpretation book is still very relevant and even very relevant to develop family law studies in Indonesia which are predominantly Muslim and even the world's largest Muslim.

\section{Conclusions}

The concept of sakinah family according to Muhammad Qurasih Shihab is if a family of ten basic construction, namely: 1). Sakinah family is a meaningful marriage that unites the soul (mind) and body. 2). Sakinah family is a marriage that brings physical and spiritual peace. 3). Sakinah family is a family that knows each other physically and mentally. 4). Sakinah family is a family who love each other physically and mentally. 5). The sakinah family is a family that loves each other physically and spiritually. 6). Sakinah families must channel each other biologically and there are offspring. 7). Sakinah family comes from all family members. 8). Sakinah family is uniting two large families of husband and wife. 9). Sakinah family is sourced from the heart (heart), then radiates out in the form of activities (husband and wife), both individuals and communities. 10). The sakinah family strongly supports the effectiveness of worship of God.

Of the ten family construction foundations above, the essence of this discussion is that the sharia maqasyid from the concept of sakinah family according to Muhammad Quraish Shihab in the interpretation of AlMishbah is mahabbatullah (love of God). Love (mawaddah) is a tree that thrives in the heart. The root is humility to the lover (warahmah), the trunk is recognition of him, the branches are fear of God and creatures so that no one stains him, the leaves are shyness humiliating and humiliated, the fruit is the unity of the heart that gives birth to cooperation, the interest is mutual keep each other's honor and cover each other's shame, the seeds are calm (sakinah), while the water that waters them is remembering and mentioning his name.

The relevance of Muhammad Quraish Shihab's thought about the sakinah family in its interpretation of the Al-Mishbah in terms of sharia maqasyid and the development of Islamic family law in Indonesia: 1). The relevance of Muhammad Quraish Shihab's thought about the sakinah family in the interpretation of al-Mishbah in terms of the sharia maqasyid is that the sakinah family must be endeavored and fought for, not originated. The form of effort and endeavor in realizing it must start from the heart (Qalbu), which is to convince the hearts of each husband and wife and 
family members (children) and extended family members (parents, parents-in-law, siblings and in-laws). 2). The relevance of Muhammad Quraish Shihab's thoughts about the sakinah family in the interpretation of al-Mishbah in terms of the development of Islamic family law in Indonesia: that the Quraish Shihab's concept of a sakinah family is relevant to marital law in Indonesia, because his concept does not conflict with marital law in Indonesia, such as choosing a partner, agreement between two candidates, and a minimum age limit. There is a difference in the purpose of marriage itself. In the marriage law article 1, which is to form a happy and eternal household (family) based on the Almighty God. Whereas in the concept M. Quraish Shihab formed a family that was "calm (sakinah)" and continued with the words "full of love (mawadah)" and "compassion (rahmah)". So overall M. Quraish Shihab's concept of a sakinah family is in accordance with Indonesian marriage law[.]

\section{REFERENCES}

Religion, Ministry, RI, al-Qur'an Translation, (Jakarta: Ministry of Religion, 2005)

Al-Jurjani, Khudzaifah, The Most Absolute Marriage of the Wrath of God, (Jombang: Cross Media)

Aminuddin, Da'wah and Family Strengthening (Kendari: State Islamic Institute)

Asnawi, Mohammad, Marriage in Discussion and Difference, (Yogyakarta: Darussalam, 2004), cet. number 1

Ayyub, Shaykh Hasan, Fiqihkelamily, (Jakarta: Pustaka Al-Kautsar, 2010)

Cole, K, Accompanying children in facing parental divorce (Jakarta: PT. Prestasi Pustaka Raya, 2004)

Dalimunthe, Mawardi, A Review of Maqashid Al-Shari'ah About the Concept of the Sakinah Family of M. Quraish Shihab In Al-Mishbah's Interpretation (Pekanbaru: Drap Dissertation of Doctor of UIN Suska Riau, 2019).

Ghazali, Abdul Rohman, Fiqh Munakahat, (Jakarta: Kencana, 2006)

Gusmian, Ishlah, Khazanah Tafsir Indonesia from Hermeneutics to Ideology, (Jakarta: Teraju, 2003)

Hasan, Maimunah, Muslim Household (Yogyakarta: Bintang Cemerlang, 2001)

Ichsan, Ahamad, Marriage Law for Muslims, (Jakarta: Pradnya Pramita, 1979)

M. Quraish Shihab, Lantern al-Qur`an, (Bandung: Mizan, 2013) 
M. Quraish Shihab, Answering 1001 Islamic Questions You Should Know (Jakarta: Lentera Hati, 2008)

The famous, Mustafa, Qudwah on the Da'wah road, translated by Ali Hasan, (Jakarta: Citra Islami Press, 1999)

Noorhidayati, Salamah, Women's Leadership in Islam: Study of the Thinking of the Interpretation of M. Quraish Shihab, Al-tahrir, Vol. 5, No. 1 (January 2005)

Nur, Djamaan, Fiqih Munakahat, (Semarang: Dimas Semarang, 1993)

Nurhadi, Analysis of the Concept of the Samara Family in Law No. 1 of 1974 concerning Marriage and KHI according to Islamic Law (Pekanbaru: STAILe, 2017)

Nuruddin, Amiur and Azhari Akmal Tarigan, Islamic Law in Indonesia, (Jakarta: Kencana, 2006)

Rafiq, Ahmad. National Seminar, "About Family Law Polemic in Indonesia During the Industrial Revolution 4.0 at Uin Suska Pekanbaru. 2018

Shihab, M. Quraish, Female, (Jakarta: Lentera Hati, 2005)

Shihab, M.Quraish, Grounding the Qur'an, (Bandung: Mizan, 1992).

Shihab, Muhamamad Quraish, Religious Logic; Position of Revelation and the Boundaries of Intellect in Islam, (Jakarta: Lentera Hati, 2005)

Shihab, Muhamamad Quraish, Mystical, Sex, and Worship, (Jakarta: Republika, 2004)

Shihab, Muhammad Qurais, Tafsir Al-Misbah (Jakarta: Lentera Ilmu, 2008)

Shihab, Muhammad Quraish, Rule of Tafsir, (Tangerang: Lentera Hati, 2013)

Shihab, Muhammad Quraish, Revealing the Divine Veil: Asma al-Husna in the Qur'anic Perspective, (Jakarta: Lentera Hati, 2001)

Shihab, Muhammad Quraish, Tafsir al-Mishbah: Messages, Impressions, and Harmony of the Qur'an, (Ciputat: Lentera Hati, 2007), Vol. I

Shihab, Muhammad Quraish, String of Gems for My Son; Message of the Qur'an for the Bride, (Bandung: Mizan, 1998), Cet. IV

Subhan, Arif, Grounded Tafsir, Tsaqafah, 2003, Vol. 1, No. 3

Ulum, Miftahul, Concept of Sakinah Family According to Tablighi Jamaah in the Perspective of Islamic Law, (Cirebon: Ministry of Religion of the Republic of Indonesia Institute of State Islamic Religion (IAIN) Sheikh Nurjati, 2012) 